\title{
BMJ Open Social media interventions for diet and exercise behaviours: a systematic review and meta-analysis of randomised controlled trials
}

\author{
Gillian Williams, Michele P Hamm, Jocelyn Shulhan, Ben Vandermeer, Lisa Hartling
}

To cite: Williams G,

Hamm MP, Shulhan J, et al. Social media interventions for diet and exercise behaviours: a systematic review and meta-analysis of randomised controlled trials. BMJ Open 2014:4:e03926.

doi:10.1136/bmjopen-2013003926

- Prepublication history and additional material for this paper is available online. To view these files please visit the journal online (http://dx.doi.org/10.1136/ bmjopen-2013-003926).

Received 4 September 2013 Revised 13 December 2013 Accepted 10 January 2014

CrossMark

Department of Pediatrics, Alberta Research Centre for Health Evidence, University of Alberta, Edmonton, Alberta, Canada

Correspondence to Lisa Hartling; hartling@ualberta.ca

\section{ABSTRACT}

Objectives: To conduct a systematic review of randomised controlled trials (RCTs) examining the use of social media to promote healthy diet and exercise in the general population.

Data sources: MEDLINE, CENTRAL, ERIC, PubMed, CINAHL, Academic Search Complete, Alt Health Watch, Health Source, Communication and Mass Media Complete, Web of Knowledge and ProQuest Dissertation and Thesis (2000-2013).

Study eligibility criteria: RCTs of social media interventions promoting healthy diet and exercise behaviours in the general population were eligible. Interventions using social media, alone or as part of a complex intervention, were included.

Study appraisal and synthesis: Study quality was assessed using the Cochrane Risk of Bias Tool. We describe the studies according to the target populations, objectives and nature of interventions, outcomes examined, and results and conclusions. We extracted data on the primary and secondary outcomes examined in each study. Where the same outcome was assessed in at least three studies, we combined data in a meta-analysis.

Results: 22 studies were included. Participants were typically middle-aged Caucasian women of mid-to-high socioeconomic status. There were a variety of interventions, comparison groups and outcomes. All studies showed a decrease in programme usage throughout the intervention period. Overall, no significant differences were found for primary outcomes which varied across studies. Meta-analysis showed no significant differences in changes in physical activity (standardised mean difference (SMD) $0.13(95 \% \mathrm{Cl}-0.04$ to 0.30$), 12$ studies) and weight (SMD -0.00 (95\% Cl -0.19 to 0.19 ), 10 studies); however, pooled results from five studies showed a significant decrease in dietary fat consumption with social media (SMD $-0.35(95 \% \mathrm{Cl}-0.68$ to -0.02$)$ ).

Conclusions: Social media may provide certain advantages for public health interventions; however, studies of social media interventions to date relating to healthy lifestyles tend to show low levels of participation and do not show significant differences between groups in key outcomes.

\section{Strengths and limitations of this study}

- This article was conducted following rigorous systematic review methodology; 11 databases were searched, not limited by language or publication type, and study selection, data extraction and quality assessment were all completed independently, in duplicate.

- This review is limited by methodology of included studies; there was poor reporting of methods for sequence generation, allocation concealment and blinding of participants, personnel and outcome assessment.

- Social media use is constantly evolving, resulting in difficulties in defining the interventions and ensuring the use of up-to-date sources.

\section{INTRODUCTION}

Overweight and obesity are characterised by abnormal or excessive fat accumulation that may impair health. ${ }^{1}$ Body mass index (BMI) is the common measure for body fat. In adults, a BMI greater than 24 is indicative of overweight status and a BMI greater than 29 indicates obesity. ${ }^{2}$ There is no universal agreement on the classification of obesity in children, but the use of growth charts and reference curves have been suggested. ${ }^{2}$ BMI does not account for factors such as lean muscle composition or waist circumference, but at a population level it is a good indicator of weight status. ${ }^{2}$

Overweight and obesity are global problems, affecting developed and developing countries. In 2008, the WHO estimated that more than 1.4 billion adults worldwide, aged 20 years and older, were overweight, and, of those, over 700 million were obese. ${ }^{1}$ These conditions lead to a variety of chronic diseases such as cardiovascular disease and type 2 diabetes, which pose a large burden on health systems. ${ }^{2}$ 
While there are pharmacological and surgical options for treatment of excessive weight, they are typically reserved for extreme situations. Lifestyle interventions involving changes in diet and physical activity levels are most commonly advocated for prevention and treatment, ${ }^{2}$ particularly decreasing calories and augmenting energy expenditure through increased exercise. Other dietary changes such as increasing fruit and vegetable consumption and decreasing sugary beverage intake are also advocated.

While there have been many studies examining the use of computer and Internet-based interventions promoting healthy diet and exercise, ${ }^{3-7}$ social media offers a new group of tools whose efficacy as an intervention for lifestyle modifications is just beginning to be evaluated. Social media can be defined as a group of online applications that allow for the creation and exchange of user-generated content, and which can be divided into five different types: (1) collaborative projects (eg, Wikipedia), (2) blogs or microblogs (eg, Wordpress and Twitter), (3) content communities (eg, YouTube), (4) social networking sites (eg, Facebook) and (5) virtual gaming or social worlds (eg, Second Life) ${ }^{8}$ These tools are a part of what was, in 2004, termed Web V.2.0: the utilisation of the World Wide Web as a platform where content is continuously modified by all users in a collaborative fashion. ${ }^{8}$

Many benefits of social media have been advocated. Social media provides a cost-effective way to increase user interaction, provide peer-to-peer support and widen access to health interventions. ${ }^{9}$ However, there are concerns about reliability and quality control of disseminated information. As social media gains in popularity as a health intervention, ${ }^{10}$ it is important to understand the impact it is having on users.

Our objective was to conduct a systematic review of randomised controlled trials (RCTs) examining the use of social media to promote healthy diet and exercise in the general population to identify (1) how social media is being used as an intervention and (2) whether it is effective.

\section{METHODS}

This systematic review followed established methods for systematic reviews ${ }^{11}$ and builds on a scoping review conducted by our group on the use of social media among patients and caregivers. ${ }^{10}$

\section{Search strategy}

A research librarian with extensive experience in systematic reviews developed the search strategy, which involved 11 databases: MEDLINE, CENTRAL, ERIC (all via the Ovid platform), PubMed (hosted by the National Library of Medicine), CINAHL, Academic Search Complete, Alt Health Watch, Health Source, Communication and Mass Media Complete (all via the EBSCO platform), Web of Knowledge, and ProQuest Dissertation and Thesis. The databases were searched from 2000 to April 2013; the search was run on 3 May 2013. The starting date of 2000 corresponded to the establishment of Web V.2.0. References of included studies were also scanned for relevant literature. The search was not restricted by language or publication status. The search strategy for MEDLINE is appended; the searches for other databases are available from authors on request.

\section{Eligibility criteria}

RCTs of social media interventions promoting healthy diet and exercise behaviours in the general population were eligible for this review. Interventions using social media, alone or as part of a complex intervention, were included based on Kaplan and Haenlein's ${ }^{8}$ classifications. We included electronic discussion boards as they involve the sharing of user-generated content. Any outcomes related to lifestyle behaviour change were considered for inclusion in this review. We excluded studies where interventions were targeted to populations with specific medical conditions such as diabetes, metabolic disorder, cardiovascular disease or eating disorders.

\section{Study selection}

Two reviewers independently screened all titles and abstracts. The full texts of 'relevant' or 'unclear' articles were subsequently evaluated for eligibility by two independent reviewers. Discrepancies were resolved through consensus.

\section{Data extraction}

Data extraction was completed by one reviewer using a standardised form in Microsoft Excel 2007 (Microsoft, Redmond, Washington, USA) and verified by a second reviewer. The data extraction form was piloted by all reviewers on a set of studies prior to use. Extracted data included study characteristics, population characteristics (target population, age and gender distribution, and setting), intervention characteristics (simple vs complex, description of intervention), outcome measures (primary and secondary), results and authors' conclusions.

\section{Quality assessment}

Study quality was assessed using the Cochrane Risk of Bias Tool ${ }^{11}$ which examines sequence generation, allocation concealment, blinding, incomplete outcome data, selective outcome reporting and other sources of bias. Risk of bias assessment was performed independently in duplicate, and differences between reviewers were resolved through consensus. Risk of bias assessments are described by study and for the review overall; results are discussed in light of some of the common limitations identified in the included set of studies.

\section{Data synthesis}

Evidence tables were developed that describe the studies according to the target populations, objectives of interventions, the nature of interventions, outcomes 
examined and general results and conclusions. We extracted data on the primary and secondary outcomes examined in each study. When there were greater than two study arms in the intervention, we extracted data from the arm with the least intervention (eg, standard care, wait-list control, active intervention without social media component) as the control group. When there were multiple comparison groups involving social media, we extracted data for the group with the fewest co-interventions in an attempt to examine the specific impact of social media.

In order to present results in a consistent manner for all studies, we calculated effect sizes (or standardised mean difference (SMD)) with $95 \%$ CIs for the primary outcomes of each study. We did not pool the results as the primary outcome varied across studies; however, we displayed the information graphically to examine the magnitude of effect of the social media interventions.

Studies comparing the same social media tool as one component in the intervention and control groups were not included in the meta-analysis, but were used for descriptive purposes. Where the same outcome was assessed in at least three studies, we combined data in a meta-analysis. For continuous outcomes, we used SMD to standardise results to a common scale. ${ }^{11}$ For continuous variables, final scores were used; we divided by the standard deviation (SD) of the final value (or baseline $\mathrm{SD}$ when the final SD was not given). All results and analyses are presented with 95\% CIs. A random effects model was used to combine results as it incorporates statistical heterogeneity that cannot readily be explained. ${ }^{11}$ We quantified heterogeneity using the $\mathrm{I}^{2}$ statistic. ${ }^{11}$ We conducted subgroup analyses to examine potential sources of heterogeneity. A priori subgroups included characteristics of the populations (ie, children vs adults) and nature of the comparator (ie, another active intervention vs no-intervention control group). We made a post hoc decision to examine duration of follow-up as a potential explanation for heterogeneity in study findings. We planned to assess for publication bias visually and graphically in the meta-analysis with the most contributing studies using Egger test. ${ }^{12}$ The Egger test is a linear regression test, evaluating the null hypothesis that the funnel plot is asymmetric. When the $p$ value is high, there is no evidence of asymmetry.

Statistical calculations were performed using Reference Manager V.5.2 (The Nordic Cochrane Centre, Copenhagen, Denmark).

\section{RESULTS}

Figure 1 shows the flow of studies through the selection process. Twenty-two randomised RCTs were included in this review. Descriptions of included studies can be found in table 1. Fifteen studies were based in the USA, ${ }^{15-18}$ 21-23 25262829 31-34 four in Australia ${ }^{13} 141927$ and three in other countries. ${ }^{20} 24{ }^{30}$ Sixteen studies intervened in an adult population $^{13-15} 19-212324$ 26-28 30-34 and six in children and

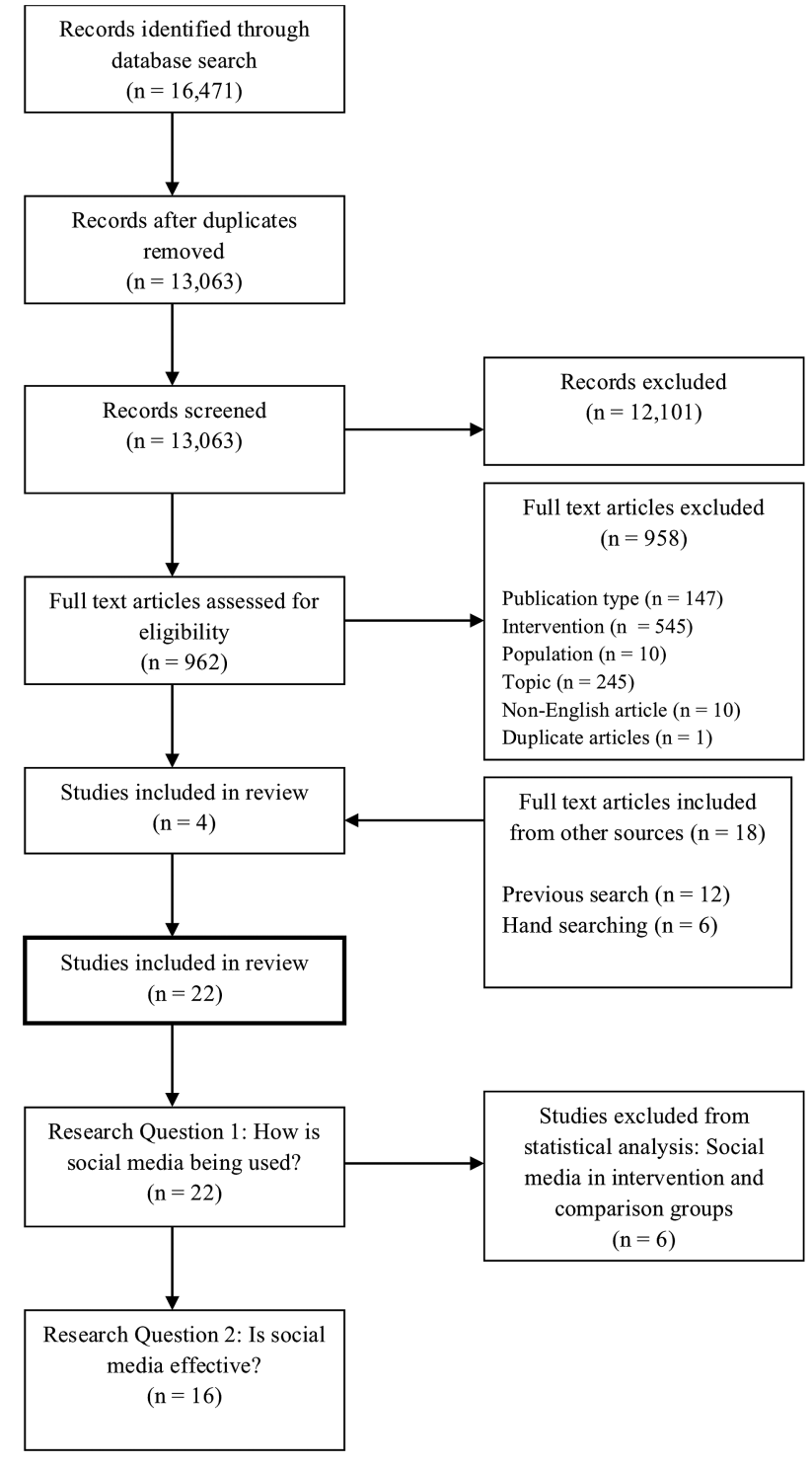

Figure 1 Flow diagram of study selection.

youth populations up to the age of $25 . \begin{array}{llll}16-18 & 22 & 25 & 29\end{array}$ Overweight or obesity were inclusion criteria in 13 studies. $^{13} 1417202123$ 26-28 31-34 Six studies targeted women exclusively $^{16} \quad 18 \quad 28 \quad 29 \quad 33 \quad 34$ while only one solely targeted men. $^{27}$

\section{How social media is being used}

The objectives of these studies were to modify behaviour. While interventions varied greatly, this was generally attempted through implementation of a complex intervention utilising discussion boards as the social media element. The distribution of social media tools used in the studies can be seen in figure 2. Interventions typically included online learning modules and self-report diaries of weight, physical activity or dietary behaviours along with a social support component using social media. A description of all interventions and comparisons can be found in table 1 . Only three studies did not use discussion boards as the exclusive social media 
Table 1 Characteristics of included studies

\begin{tabular}{|c|c|c|c|c|c|}
\hline $\begin{array}{l}\text { Author, year } \\
\text { (country) }\end{array}$ & $\begin{array}{l}\text { Target } \\
\text { population }\end{array}$ & $\begin{array}{l}\text { Objectives (length of } \\
\text { intervention) }\end{array}$ & Social media intervention & Comparison & Primary outcome measure \\
\hline $\begin{array}{l}\text { Booth, } 2008 \\
\text { (Australia) }^{13}\end{array}$ & $\begin{array}{l}\text { Overweight and } \\
\text { obese adults }\end{array}$ & $\begin{array}{l}\text { Determine whether an } \\
\text { Internet-based, online weight } \\
\text { reduction programme that } \\
\text { includes dietary advice plus } \\
\text { exercise would be more effective } \\
\text { in reducing weight and results in } \\
\text { more positive lifestyle changes } \\
\text { than an exercise only } \\
\text { programme (12 weeks) }\end{array}$ & $\begin{array}{l}\text { Discussion board as part of a } \\
\text { website to record daily steps and } \\
\text { set dietary goals with exercise } \\
\text { and diet recommendation } \\
\text { (n enrolled }=40, \mathrm{n} \text { completed }=27 \text {, } \\
\mathrm{n} \text { analysed }=27 \text { ) }\end{array}$ & $\begin{array}{l}\text { Discussion board as part of } \\
\text { a website with exercise } \\
\text { recommendations } \\
\text { ( } \mathrm{n} \text { enrolled }=33 \text {, } \\
\mathrm{n} \text { completed }=26 \text {, } \\
\mathrm{n} \text { analysed }=26 \text { ) }\end{array}$ & $\begin{array}{l}\text { BMI }\left(\mathrm{kg} / \mathrm{m}^{2} ; \text { objective }\right. \\
\text { outcome) }\end{array}$ \\
\hline $\begin{array}{l}\text { Brindal, } 2012 \\
\text { (Australia) }^{14}\end{array}$ & $\begin{array}{l}\text { Overweight and } \\
\text { obese adults }\end{array}$ & $\begin{array}{l}\text { Determine whether supportive } \\
\text { features and personalisation in a } \\
\text { web-based lifestyle intervention } \\
\text { affect retention and weight loss } \\
\text { (12 weeks) }\end{array}$ & $\begin{array}{l}\text { Social support through a social } \\
\text { networking programme as part of } \\
\text { an interactive website that } \\
\text { provided dietary information, } \\
\text { interactive tools such as } \\
\text { real-time dietary compliance } \\
\text { visualisations and an interactive } \\
\text { meal planner ( } \mathrm{n} \text { enrolled=3935, } \mathrm{n} \\
\text { completed=206, } \mathrm{n} \\
\text { analysed }=1281 \text { ) }\end{array}$ & $\begin{array}{l}\text { Non-interactive online weight } \\
\text { loss programme ( } \mathrm{n} \\
\text { enrolled }=183, \mathrm{n} \\
\text { completed }=16, \mathrm{n} \\
\text { analysed }=53 \text { ) }\end{array}$ & $\begin{array}{l}\text { Body weight (\% of initial } \\
\text { weight; self-reported } \\
\text { outcome) }\end{array}$ \\
\hline $\begin{array}{l}\text { Carr, } 2013 \\
(\text { USA })^{15}\end{array}$ & $\begin{array}{l}\text { Healthy } \\
\text { sedentary adults }\end{array}$ & $\begin{array}{l}\text { Test the efficacy of the newly } \\
\text { enhanced Internet intervention in } \\
\text { relation to six reputable, publicly } \\
\text { available physical activity } \\
\text { promoting websites ( } 6 \text { months) }\end{array}$ & $\begin{array}{l}\text { A discussion forum with an } \\
\text { expert moderator as part of a } \\
\text { website with tailored, } \\
\text { motivational physical activity } \\
\text { messages after completing } \\
\text { monthly online questionnaires, } \\
\text { physical activity tracking and } \\
\text { goal setting calendar, regular } \\
\text { peer activity updates and } \\
\text { exercise videos ( } \mathrm{n} \text { enrolled }=25, \mathrm{n} \\
\text { completed }=23, \mathrm{n} \text { analysed }=25 \text { ) }\end{array}$ & $\begin{array}{l}\text { Access to a list of six } \\
\text { reputable, publicly available } \\
\text { physical activity-promoting } \\
\text { websites that have been } \\
\text { demonstrated to increase } \\
\text { physical activity and } \\
\text { successfully retain } \\
\text { participants. Discussion } \\
\text { boards included } \\
\text { (n enrolled=28, } \\
\text { n completed }=22 \text {, } \\
\text { n analysed }=28 \text { ) }\end{array}$ & $\begin{array}{l}\text { Physical activity levels (min/ } \\
\text { week; self-reported outcome) }\end{array}$ \\
\hline $\begin{array}{l}\text { Cavallo, } 2012 \\
\text { (USA) }^{16}\end{array}$ & $\begin{array}{l}\text { Female } \\
\text { undergraduate } \\
\text { students }\end{array}$ & $\begin{array}{l}\text { Test the efficacy of a physical } \\
\text { activity intervention that } \\
\text { combined education, physical } \\
\text { activity monitoring and online } \\
\text { social networking to increase } \\
\text { social support for physical } \\
\text { activity (12 weeks) }\end{array}$ & $\begin{array}{l}\text { An intervention-related Facebook } \\
\text { group in addition to a website } \\
\text { containing educational } \\
\text { information related to physical } \\
\text { activity and a self-monitoring tool } \\
\text { that allowed participants to set } \\
\text { goals, track their daily physical } \\
\text { activity and view a chart } \\
\text { depicting their progress relative } \\
\text { to their goal and to national }\end{array}$ & $\begin{array}{l}\text { Limited version of the study } \\
\text { website without } \\
\text { self-monitoring features and } \\
\text { emails throughout the study } \\
\text { with links to news stories } \\
\text { relating to physical activity } \\
\text { shared in the intervention's } \\
\text { Facebook group. } \\
\text { (n enrolled=67, }\end{array}$ & $\begin{array}{l}\text { Perceived informational social } \\
\text { support (Chogahara's Social } \\
\text { Influence on Physical Activity } \\
\text { questionnaire; self-reported } \\
\text { outcome) }\end{array}$ \\
\hline
\end{tabular}


Table 1 Continued

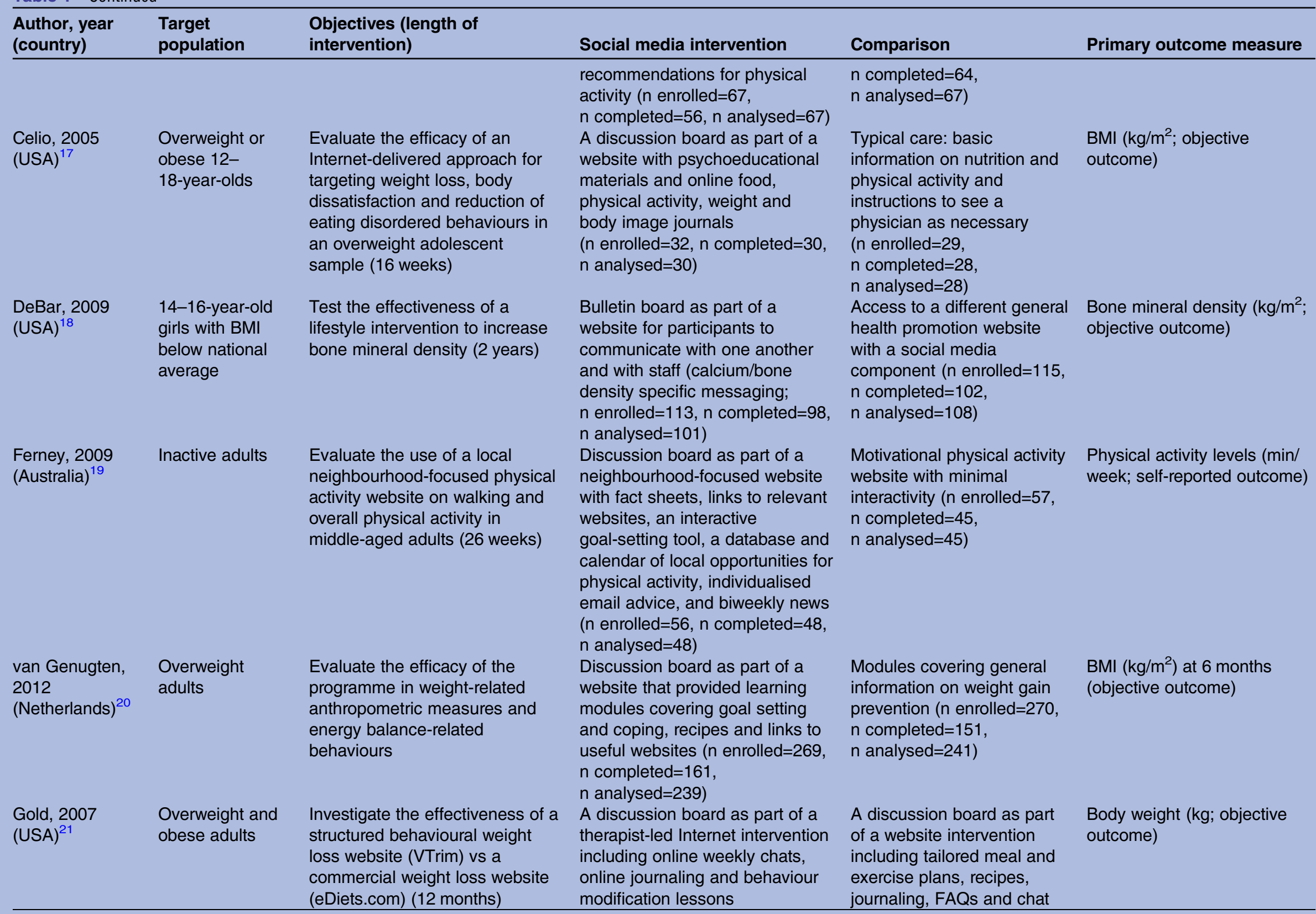




\begin{tabular}{|c|c|c|c|c|c|}
\hline $\begin{array}{l}\text { Author, year } \\
\text { (country) }\end{array}$ & $\begin{array}{l}\text { Target } \\
\text { population }\end{array}$ & $\begin{array}{l}\text { Objectives (length of } \\
\text { intervention) }\end{array}$ & Social media intervention & Comparison & Primary outcome measure \\
\hline & & & $\begin{array}{l}\text { ( } \mathrm{n} \text { enrolled }=60, \mathrm{n} \text { completed }=40 \\
\mathrm{n} \text { analysed }=40 \text { ) }\end{array}$ & $\begin{array}{l}\text { rooms ( } \mathrm{n} \text { enrolled }=62 \\
\mathrm{n} \text { completed }=n=48 \text { ) }\end{array}$ & \\
\hline $\begin{array}{l}\text { Harvey-Berino, } \\
2004(\text { USA) }\end{array}$ & $\begin{array}{l}\text { Overweight and } \\
\text { obese adults }\end{array}$ & $\begin{array}{l}\text { Investigate the efficacy of an } \\
\text { Internet weight maintenance } \\
\text { programme (6-month } \\
\text { intervention,18-months } \\
\text { maintenance) }\end{array}$ & $\begin{array}{l}\text { Discussion group as part of an } \\
\text { Internet intervention including } \\
\text { therapist-led problem-solving } \\
\text { discussions and biweekly email } \\
\text { contact with the therapist where } \\
\text { participants reported weight, } \\
\text { dietary intake and exercise } \\
\text { (n enrolled }=77, \mathrm{n} \text { completed }=52 \text {, } \\
\mathrm{n} \text { analysed }=52 \text { ) }\end{array}$ & $\begin{array}{l}\text { Participants randomised to } \\
\text { the M-IPS condition } \\
\text { continued to meet in-person } \\
\text { over ITV, monthly, for the } \\
\text { first } 6 \text { months of the } \\
12-\text { month weight } \\
\text { maintenance condition. At } \\
\text { these meetings, weight was } \\
\text { measured and participants } \\
\text { attended an hour-long } \\
\text { weight maintenance support } \\
\text { group. They were } \\
\text { encouraged to continue } \\
\text { self-monitoring, although } \\
\text { their diaries were not } \\
\text { reviewed by the therapist. } \\
\text { Participants in this group } \\
\text { were not contacted between } \\
\text { monthly meetings and there } \\
\text { was no contact from months } \\
7-12(\mathrm{n} \text { enrolled=78, } \\
\mathrm{n} \text { completed=63, } \\
\mathrm{n} \text { analysed=63) }\end{array}$ & $\begin{array}{l}\text { Body weight (kg; objective } \\
\text { outcome) }\end{array}$ \\
\hline $\begin{array}{l}\text { Hurling, } 2007 \\
(\text { UK) }\end{array}$ & Healthy adults & $\begin{array}{l}\text { Evaluate the impact of a physical } \\
\text { activity programme based on the } \\
\text { Internet and mobile phone } \\
\text { technology ( } 9 \text { weeks) }\end{array}$ & $\begin{array}{l}\text { Discussion board as part of an } \\
\text { intervention including tailored } \\
\text { solutions for perceived barriers, } \\
\text { a schedule to plan weekly } \\
\text { exercise sessions with mobile } \\
\text { phone and email reminders, and } \\
\text { real-time accelerometer feedback }\end{array}$ & $\begin{array}{l}\text { Verbal support } \\
\text { ( } \mathrm{n} \text { enrolled }=30 \\
\mathrm{n} \text { completed }=30 \\
\mathrm{n} \text { analysed }=30 \text { ) }\end{array}$ & $\begin{array}{l}\text { Physical activity (minutes } \\
\text { spent in metabolic equivalent } \\
\text { ranges (MET) of greater than } \\
\text { three indicating moderate } \\
\text { physical activity per week; } \\
\text { objective measure) }\end{array}$ \\
\hline
\end{tabular}

Continued 
Table 1 Continued

\begin{tabular}{|c|c|c|c|c|c|}
\hline $\begin{array}{l}\text { Author, year } \\
\text { (country) }\end{array}$ & $\begin{array}{l}\text { Target } \\
\text { population }\end{array}$ & $\begin{array}{l}\text { Objectives (length of } \\
\text { intervention) }\end{array}$ & Social media intervention & Comparison & Primary outcome measure \\
\hline & & & $\begin{array}{l}\text { ( } \mathrm{n} \text { enrolled }=47, \mathrm{n} \text { completed }=47 \\
\mathrm{n} \text { analysed }=47 \text { ) }\end{array}$ & & \\
\hline $\begin{array}{l}\text { Lao, } 2011 \\
(\text { USA })^{25}\end{array}$ & $\begin{array}{l}\text { 9th and 10th } \\
\text { grade students }\end{array}$ & $\begin{array}{l}\text { Evaluate the impact and } \\
\text { feasibility of Individual Nutrition } \\
\text { Health Plans ( } 8 \text { weeks) }\end{array}$ & $\begin{array}{l}\text { Nutrition curriculum administered } \\
\text { through text, Facebook and } \\
\text { Twitter (including a social } \\
\text { networking group to promote the } \\
\text { chosen health goal and weekly } \\
\text { motivational tweets; } \\
\text { n enrolled=106, n completed=81, } \\
\text { n analysed }=70 \text { ) }\end{array}$ & $\begin{array}{l}\text { No treatment comparison } \\
\text { group (data were not } \\
\text { analysed for this study; } \\
\text { n enrolled }=86 \text {, } \\
\text { n completed }=57 \\
\text { n analysed }=36 \text { ) }\end{array}$ & $\begin{array}{l}\text { Health behaviour assessed } \\
\text { from baseline (beverage } \\
\text { choice, physical activity, fruit } \\
\text { and vegetable consumption } \\
\text { OR fast food behaviours; } \\
\text { self-report) }\end{array}$ \\
\hline $\begin{array}{l}\text { Micco, } 2007 \\
(\text { USA) }\end{array}$ & $\begin{array}{l}\text { Overweight and } \\
\text { obese adults }\end{array}$ & $\begin{array}{l}\text { Determine whether the Internet } \\
\text { can stand alone as a vehicle to } \\
\text { deliver behavioural obesity } \\
\text { treatment or whether the addition } \\
\text { of limited in-person support is } \\
\text { more effective ( } 12 \text { months) }\end{array}$ & $\begin{array}{l}\text { Once a month in person } \\
\text { meetings along with website } \\
\text { access to a discussion board, } \\
\text { lessons, eating guides, contests, } \\
\text { a journaling feature and } \\
\text { progressive charts } \\
\text { ( } \mathrm{n} \text { enrolled }=61, \mathrm{n} \text { completed }=38 \text {, } \\
\mathrm{n} \text { analysed }=61 \text { ) }\end{array}$ & $\begin{array}{l}\text { Once a month online chat } \\
\text { meetings along with website } \\
\text { access to a discussion } \\
\text { board, eating guides, } \\
\text { contests, a journaling } \\
\text { feature and progressive } \\
\text { charts ( } \mathrm{n} \text { enrolled }=62 \text {, } \\
\text { n completed=39, } \\
\text { n analysed }=62 \text { ) }\end{array}$ & $\begin{array}{l}\text { Body weight (kg; objective } \\
\text { outcome) }\end{array}$ \\
\hline $\begin{array}{l}\text { Morgan, } 2011 \\
(\text { Australia })^{27}\end{array}$ & $\begin{array}{l}\text { Overweight and } \\
\text { obese men }\end{array}$ & $\begin{array}{l}\text { Determine whether men were } \\
\text { able to maintain weight loss } \\
9 \text {-month postintervention and to } \\
\text { comprehensively evaluate the } \\
\text { programme by collecting } \\
\text { information regarding the } \\
\text { experience of men taking part in } \\
\text { the trial ( } 3 \text { months) }\end{array}$ & $\begin{array}{l}\text { A discussion board as part of an } \\
\text { Internet intervention including } \\
\text { weight and diet monitoring with } \\
\text { feedback and one face-to-face } \\
\text { information session on weight } \\
\text { loss ( } \mathrm{n} \text { enrolled=34, } \\
\mathrm{n} \text { completed=26, } \mathrm{n} \text { analysed=34) }\end{array}$ & $\begin{array}{l}\text { One separate face-to-face } \\
\text { information session on } \\
\text { weight loss ( } \mathrm{n} \text { enrolled=31, } \\
\mathrm{n} \text { completed }=20 \\
\mathrm{n} \text { analysed }=31 \text { ) }\end{array}$ & $\begin{array}{l}\text { Body weight (kg; objective } \\
\text { outcome) }\end{array}$ \\
\hline $\begin{array}{l}\text { Pullen, } 2008 \\
\text { (USA) }^{28}\end{array}$ & $\begin{array}{l}\text { Overweight and } \\
\text { obese rural } \\
\text { women aged } \\
50-69 \text { years }\end{array}$ & $\begin{array}{l}\text { Evaluate feasibility and efficacy } \\
\text { of using Internet weight loss } \\
\text { interventions to promote weight } \\
\text { loss, healthy eating and physical } \\
\text { activity ( } 3 \text { months) }\end{array}$ & $\begin{array}{l}\text { Discussion board as part of a } \\
\text { website that provided an eating } \\
\text { plan, self-monitoring tools and } \\
\text { weekly newsletters } \\
\text { ( } \mathrm{n} \text { enrolled }=11, \mathrm{n} \text { completed }=8 \text {, } \\
\mathrm{n} \text { analysed }=8 \text { ) }\end{array}$ & $\begin{array}{l}\text { Access to a website that } \\
\text { provided an eating plan, } \\
\text { self-monitoring tools and } \\
\text { weekly newsletters } \\
\text { ( } \mathrm{n} \text { enrolled }=10 \text {, } \\
\text { completed }=8, \mathrm{n} \text { analysed=8) }\end{array}$ & $\begin{array}{l}\text { Body weight (lbs; objective } \\
\text { outcome) }\end{array}$ \\
\hline $\begin{array}{l}\text { Rydell, } 2005 \\
(\text { USA) } \\
{ }^{29}\end{array}$ & $\begin{array}{l}\text { Preadolescent } \\
\text { girl scouts aged } \\
10-12 \text { years }\end{array}$ & $\begin{array}{l}\text { Increase bone mass gains } \\
\text { among } 10-12 \text {-year-old girls } \\
\text { through increasing calcium-rich } \\
\text { food intake and weight-bearing } \\
\text { physical activity ( } 2 \text { years) }\end{array}$ & $\begin{array}{l}\text { Discussion board as part of an } \\
\text { interactive website with games, } \\
\text { news, recipes and a calendar } \\
\text { along with intervention specific } \\
\text { messaging at girl scout meetings } \\
\text { (n enrolled }=15 \text { troupes, } \\
\text { n completed }=15 \text { troupes, } \\
n \text { analysed=15 troupes) }\end{array}$ & $\begin{array}{l}\text { No intervention } \\
\text { ( } \mathrm{n} \text { enrolled }=15 \text { troupes, } \\
\mathrm{n} \text { completed }=15 \text { troupes, } \\
\mathrm{n} \text { analysed }=15 \text { troupes) }\end{array}$ & $\begin{array}{l}\text { Change in bone mineral } \\
\text { content ( } \mathrm{g} \text {; objective } \\
\text { outcome) }\end{array}$ \\
\hline
\end{tabular}




$\begin{array}{lll}\begin{array}{l}\text { Tate, } 2001 \\ (\text { USA })^{31}\end{array} & \begin{array}{l}\text { Healthy } \\ \text { overweight adults }\end{array} & \begin{array}{l}\text { Determine whether a structured } \\ \text { Internet behavioural weight loss } \\ \text { programme produces greater } \\ \text { initial weight loss and changes in } \\ \text { waist circumference than a } \\ \text { weight loss education website } \\ \text { (6 months) }\end{array}\end{array}$

Tate, 2006

$(\text { USA })^{32}$

Webber, 2010 Overweight or (USA) $)^{33}$

obese women
Overweight and obese adults
(6 months)

Determine the short-term efficacy of a self-directed Internet weight loss programme compared with the same programme supplemented with behavioural counselling from either a computer-automated tailored system or from a human counsellor (6 months)

Examine changes in motivation and the relationship of motivation to adherence to self-monitoring and weight loss in an Internet

behavioural weight-loss intervention (16 weeks)
Social media intervention

A discussion board as part of a website with tailored physical activity advice, goal setting weekly plan, strength and

flexibility exercises, start-to-run programme, links, contact information and emails to invite participants to view other relevant websites ( $n$ enrolled $=173$,

n completed $=103$

$n$ analysed $=173$ )

A bulletin board to facilitate social support, a weekly dietary and physical activity self-report diary, the ability to contact a therapist, and weekly lesson emails in addition to the control treatment ( $\mathrm{n}$ enrolled $=46$ $n$ completed $=33, n$ analysed $=32$ containing a brief review of

Discussion board as part of a

\section{$\begin{array}{ll}\text { recipes and a weight loss } & \text { loss ebuddy ne } \\ \text { ebuddy network system } & \text { (n enrolled }=67,\end{array}$}

( $\mathrm{n}$ enrolled $=64, \mathrm{n}$ completed $=52, \quad \mathrm{n}$ completed $=59$, $\mathrm{n}$ analysed $=64$ )

Weekly group chat in addition to

the control intervention

( $n$ enrolled $=33, \mathrm{n}$ completed $=33$, $\mathrm{n}$ analysed $=33$ )

Weekly weight loss tips,
A $1 \mathrm{~h}$ lesson on behavioura weight control, a website basic information related to weight loss and an organised directory of selected Internet resources about diet, exercise, self monitoring and other resources ( $n$ enrolled $=45$, n completed $=32$,

$\mathrm{n}$ analysed $=30$ )

Access to website with weekly reporting and graphs of weight, weekly email prompts to report weight, weekly weight loss tips via email, recipes and a weight loss ebuddy network system $\mathrm{n}$ analysed $=67$ )

weekly lesson postings, a

Body weight (kg; objective outcome)

Primary outcome measure

Moderate-to-vigorous physical activity levels (min/week self-reported outcome)

Body weight (kg; objective outcome)

Body weight (kg; objective outcome)

message board feature and

links to self-help diet,

exercise, behavioural

modification resources

available on the web, plus a 

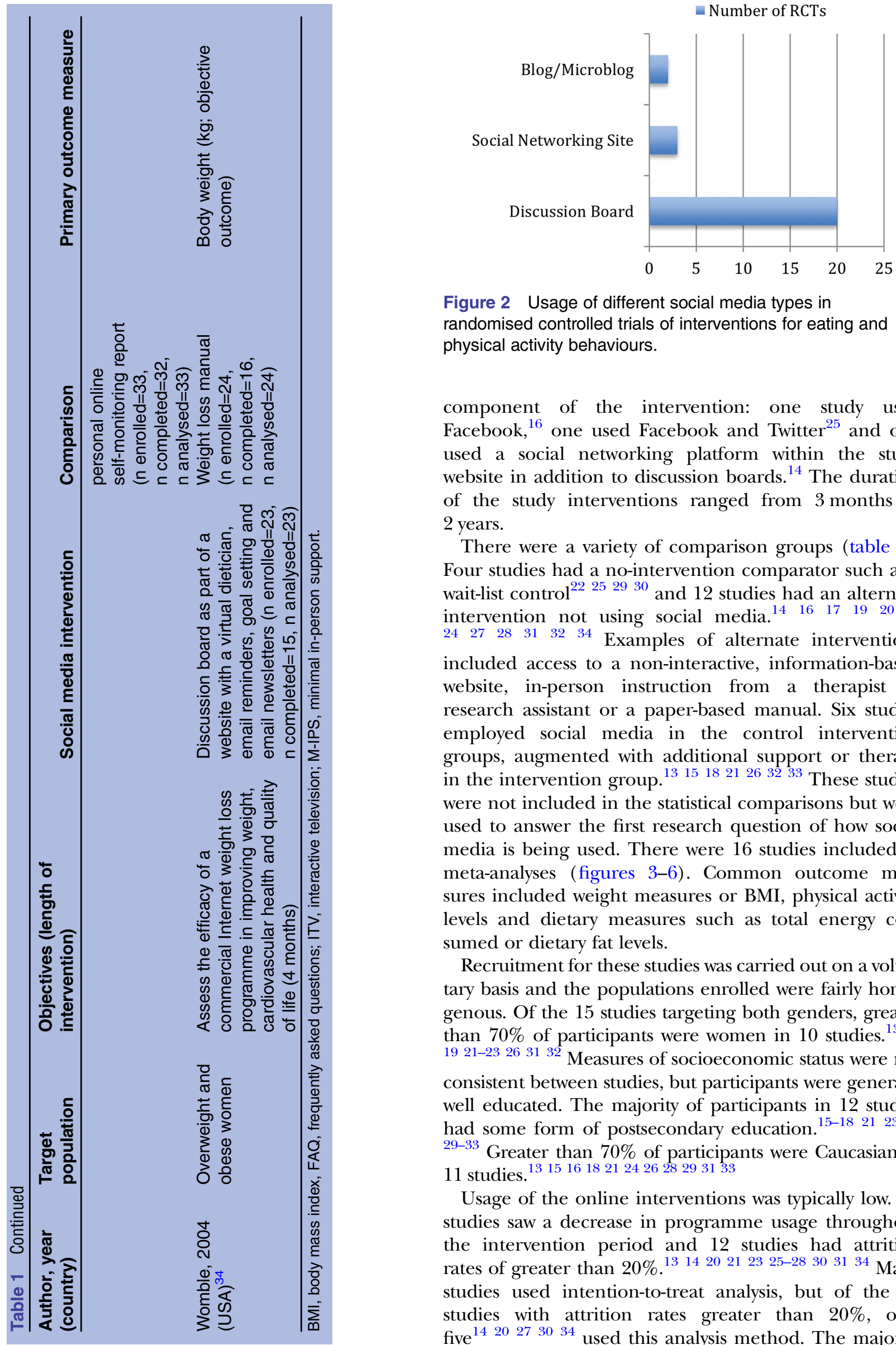

Figure 2 Usage of different social media types in randomised controlled trials of interventions for eating and physical activity behaviours.

component of the intervention: one study used Facebook, ${ }^{16}$ one used Facebook and Twitter ${ }^{25}$ and one used a social networking platform within the study website in addition to discussion boards. ${ }^{14}$ The duration of the study interventions ranged from 3 months to 2 years.

There were a variety of comparison groups (table 1 ). Four studies had a no-intervention comparator such as a wait-list control ${ }^{22} 252930$ and 12 studies had an alternate

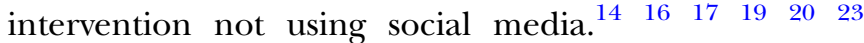
$\begin{array}{lllllll}24 & 27 & 28 & 31 & 32 & 34 & \text { Examples of alternate interventions }\end{array}$ included access to a non-interactive, information-based website, in-person instruction from a therapist or research assistant or a paper-based manual. Six studies employed social media in the control intervention groups, augmented with additional support or therapy in the intervention group. ${ }^{13151821263233}$ These studies were not included in the statistical comparisons but were used to answer the first research question of how social media is being used. There were 16 studies included in meta-analyses (figures 3-6). Common outcome measures included weight measures or BMI, physical activity levels and dietary measures such as total energy consumed or dietary fat levels.

Recruitment for these studies was carried out on a voluntary basis and the populations enrolled were fairly homogenous. Of the 15 studies targeting both genders, greater than $70 \%$ of participants were women in 10 studies. $^{13-15}$ 19 21-23 263132 Measures of socioeconomic status were not consistent between studies, but participants were generally well educated. The majority of participants in 12 studies had some form of postsecondary education. ${ }^{15-18} 212326$ ${ }^{29-33}$ Greater than $70 \%$ of participants were Caucasian in 11 studies. ${ }^{13} 15161821242628293133$

Usage of the online interventions was typically low. All studies saw a decrease in programme usage throughout the intervention period and 12 studies had attrition rates of greater than 20\%. ${ }^{13} 14202123$ 25-28 303134 Many studies used intention-to-treat analysis, but of the 12 studies with attrition rates greater than $20 \%$, only five $^{1420273034}$ used this analysis method. The majority 


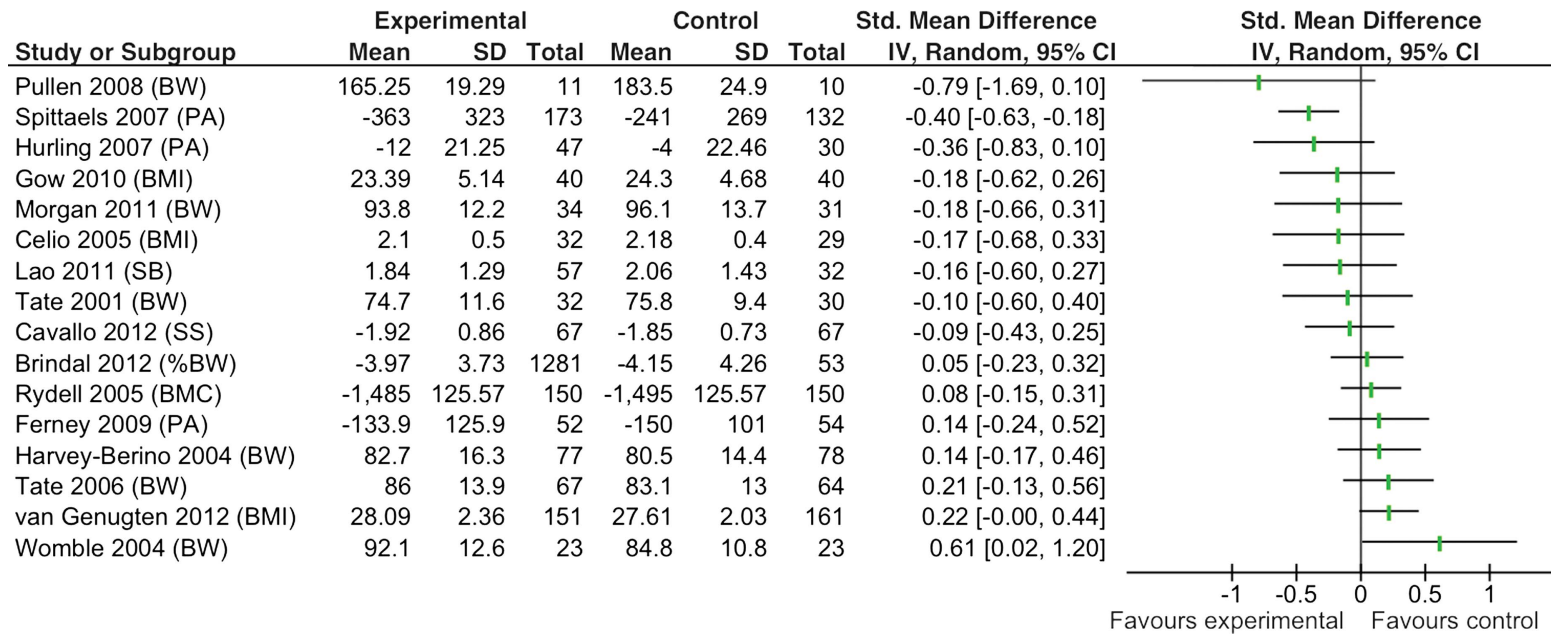

Figure 3 Effect sizes of primary outcomes. BMC, bone mineral content; BMI, body mass index; BW, body weight; PA, physical activity; SB, sweetened beverage intake; SS, social support.

of studies acknowledged the feasibility of social media interventions and 13 studies $^{13-15} 19202324$ 27-32 recommended further research to elucidate ways to determine optimal intensity of intervention and to increase participation.

\section{Quality assessment}

The Cochrane Risk of Bias Tool ${ }^{11}$ was applied to all 22 studies; none were excluded based on quality assessment. All studies were rated as unclear or high risk of bias (table 2). Sequence generation and allocation concealment were poorly reported. Most studies had high risk of bias due to incomplete outcome data and attrition being unaccounted for. Other biases included baseline imbalances and analysis of individual participants despite group randomisation.

\section{Effectiveness of social media}

Overall, no significant differences were found for primary outcomes (figure 3). The median effect size was 0.095 in favour of the intervention and ranged from 0.79 in favour of the intervention to 0.61 in favour of the comparator group. Subgroup analysis by population (children/youth vs adults) and comparison group (active vs no intervention) did not show any significant differences. Two of the individual studies showed a significant difference in their primary outcome; in one study, the primary outcome was physical activity, while in the other study, the primary outcome was body weight. In the first case, there was a significant difference in favour of the social media intervention; however, in the other case, a greater difference was observed in the comparison groups. Detailed results of the author's conclusions can be found in table 3. Authors' conclusions were either positive in 10 studies $^{13}$ 17-1921 2224283031 or neutral in 12 studies ${ }^{14-16} 202325-$ 2729 32-34; in 12 studies, authors recommended future research. ${ }^{13-15} 1920232428-32$

Outcomes commonly assessed across studies included physical activity levels, weight and dietary fat intake. Changes in physical activity (SMD 0.13 (95\% CI -0.04 to $0.30), 12$ studies; figure 4) and weight (SMD $0.00(95 \%$ CI -0.19 to 0.19$)$, 10 studies; figure 5) were not significantly different between participants in the social media and control groups. Pooled results from five studies showed that dietary fat consumption decreased significantly among participants exposed to social media

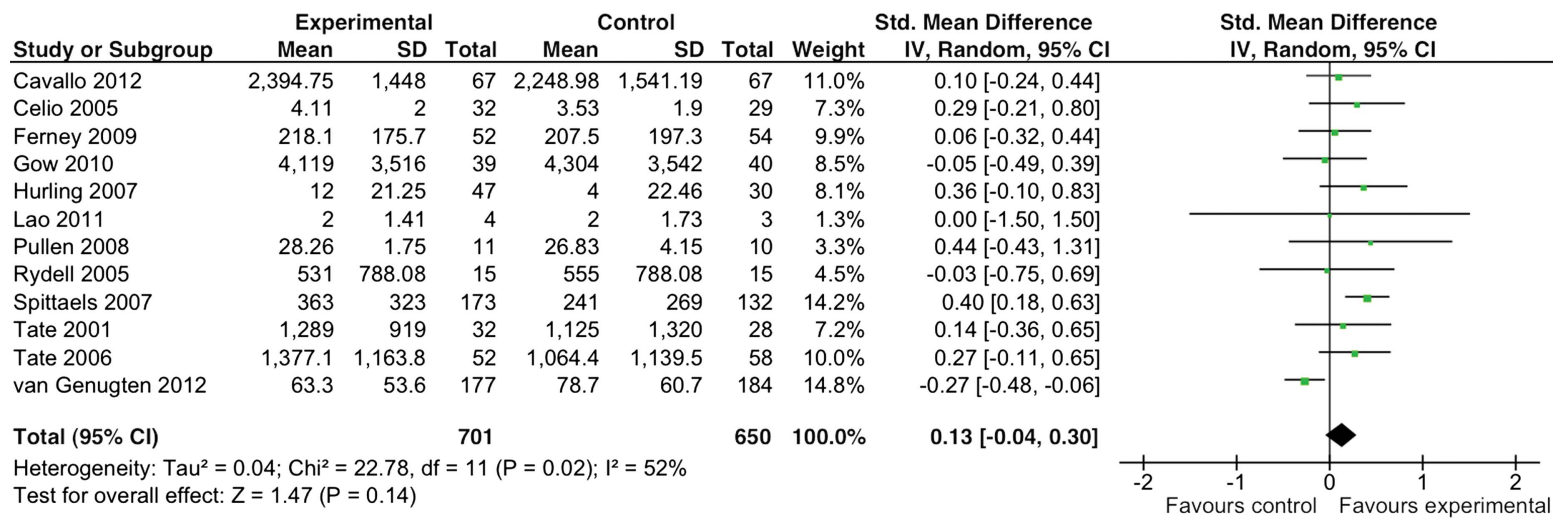

Figure 4 Forest plot of social media for physical activity. 


\begin{tabular}{|c|c|c|c|c|c|c|c|c|c|}
\hline \multirow[b]{2}{*}{ Study or Subgroup } & \multicolumn{3}{|c|}{ Experimental } & \multicolumn{3}{|c|}{ Control } & \multicolumn{2}{|r|}{ Std. Mean Difference } & \multirow{2}{*}{$\begin{array}{l}\text { Std. Mean Difference } \\
\text { IV, Random, } 95 \% \mathrm{Cl}\end{array}$} \\
\hline & Mean & SD & Total & Mean & SD & Total & Weight & IV, Random, $95 \% \mathrm{Cl}$ & \\
\hline Celio 2005 & 2.1 & 0.5 & 32 & 2.18 & 0.4 & 29 & $8.6 \%$ & $-0.17[-0.68,0.33]$ & \\
\hline Gow 2010 & 23.39 & 5.14 & 40 & 24.3 & 4.68 & 40 & $10.1 \%$ & $-0.18[-0.62,0.26]$ & \\
\hline Harvey-Berino 2004 & 82.7 & 16.3 & 77 & 80.5 & 14.4 & 78 & $13.7 \%$ & $0.14[-0.17,0.46]$ & \\
\hline Hurling 2007 & -0.24 & 0.75 & 47 & 0.1 & 0.77 & 30 & $9.5 \%$ & $-0.44[-0.91,0.02]$ & \\
\hline Morgan 2011 & 93.8 & 12.2 & 34 & 96.1 & 13.7 & 31 & $8.9 \%$ & $-0.18[-0.66,0.31]$ & \\
\hline Pullen 2008 & 165.25 & 19.29 & 11 & 183.5 & 24.9 & 10 & $3.7 \%$ & $-0.79[-1.69,0.10]$ & \\
\hline Tate 2001 & 74.7 & 11.6 & 32 & 75.8 & 9.4 & 30 & $8.7 \%$ & $-0.10[-0.60,0.40]$ & \\
\hline Tate 2006 & 86 & 13.9 & 67 & 83.1 & 13 & 64 & $12.8 \%$ & $0.21[-0.13,0.56]$ & \\
\hline van Genugten 2012 & 28.09 & 2.36 & 151 & 27.61 & 2.03 & 161 & $17.0 \%$ & $0.22[-0.00,0.44]$ & \\
\hline Womble 2004 & 92.1 & 12.6 & 23 & 84.8 & 10.8 & 23 & $7.0 \%$ & $0.61[0.02,1.20]$ & \\
\hline Total $(95 \% \mathrm{Cl})$ & & & 514 & & & 496 & $100.0 \%$ & $-0.00[-0.19,0.19]$ & \\
\hline $\begin{array}{l}\text { Heterogeneity: } \text { Tau }^{2} \\
\text { Test for overall effect }\end{array}$ & $\begin{array}{l}0.04 ; \mathrm{Chi}^{2} \\
\mathrm{Z}=0.03(\end{array}$ & $\begin{array}{l}2=17.6 \\
(P=0.98\end{array}$ & $d f=$ & $9(P=0$. & $.04) ; 1^{2}$ & $=49 \%$ & & & $\begin{array}{lll}-1 & -0.5 & 0\end{array}$ \\
\hline
\end{tabular}

Figure 5 Forest plot of social media for change in weight.

(SMD -0.35 (95\% CI -0.68 to -0.02$)$; figure 6$)$. The pooled effect size was small to moderate; however, there was substantial heterogeneity across studies $\left(\mathrm{I}^{2}=66 \%\right)$. Differences in comparison groups may have contributed to this heterogeneity. There was no indication of publication bias $(\mathrm{p}=0.44)$.

\section{DISCUSSION}

This comprehensive systematic review of the literature shows that social media is being commonly used as an intervention to affect a variety of outcomes related to healthy diet and exercise. Most of the current research have been conducted in the USA with overweight or obese adult populations. Discussion boards are the most commonly used form of social media. This technology is most often used as a part of complex interventions that employ other techniques such as learning modules, online self-report journals and even in-person support.

Our results did not show a significant difference between social media interventions and alternate or no intervention controls in promoting healthy diets and behaviours. Meta-analyses of physical activity levels and change in weight showed no benefits from the intervention compared with the control. Pooled results of five studies showed a significant reduction in dietary fat consumption in the social media group. The effect size was moderate; however, there was significant heterogeneity between studies suggesting that the effect may vary due to other factors. Subgroup analyses showed no significant differences in the effects of the intervention according to age, or the nature of the comparator.

A lack of effect in terms of changes in weight and physical activity levels may be due to the inherent difficulty in affecting behaviour change as observed across many different types of interventions. Although initial positive changes may be seen, behaviour change in the long term is often not sustained. Our findings are consistent with evaluations examining other interventions targeting healthy behaviours to manage weight. For example, a systematic review of interventions to manage weight based on the transtheoretical model stages of change model concluded that these interventions resulted in minimal weight loss (Tuah). A systematic review of major commercial weight loss programmes in the USA showed minimal evidence to support these interventions; moreover, they found that the interventions "were associated with high costs, high attrition rates and a high probability of regaining $50 \%$ or more of lost weight in 1-2 years" (Tsai). In an overview by Kohl et al, online behaviour change strategies that were more promising included the use of tailored feedback, theory, interactivity, goal setting and a combination of online and in-person support. ${ }^{37}$ The use of these strategies in conjunction with mobile connective technology has been successful, and may also enhance the success rate when using social media interventions. ${ }^{38}$

Attrition was generally high in these studies which may introduce bias into results. However, participant loss is a common problem, and Eysenbach proposes more extensive reporting of adherence rates in Internet health

\begin{tabular}{|c|c|c|c|c|c|c|c|c|c|}
\hline \multirow[b]{2}{*}{ Study or Subgroup } & \multicolumn{3}{|c|}{ Experimental } & \multicolumn{3}{|c|}{ Control } & \multicolumn{2}{|r|}{ Std. Mean Difference } & \multirow{2}{*}{$\begin{array}{l}\text { Std. Mean Difference } \\
\text { IV, Random, } 95 \% \mathrm{Cl}\end{array}$} \\
\hline & Mean & SD & Total & Mean & SD & Total & Weight & IV, Random, $95 \% \mathrm{Cl}$ & \\
\hline Celio 2005 & 14.94 & 6.44 & 32 & 19.07 & 8.7 & 29 & $18.5 \%$ & $-0.54[-1.05,-0.02]$ & \\
\hline Gow 2010 & 104.6 & 14.5465 & 40 & 104.56 & 14.5465 & 40 & $21.1 \%$ & $0.00[-0.44,0.44]$ & \\
\hline Pullen 2008 & 31.96 & 6.85 & 8 & 37.78 & 6.42 & 8 & $7.7 \%$ & $-0.83[-1.86,0.21]$ & \\
\hline Tate 2006 & 33.1 & 4.9 & 52 & 37.3 & 6.6 & 54 & $22.8 \%$ & $-0.72[-1.11,-0.32]$ & \\
\hline van Genugten 2012 & 15.4 & 6 & 177 & 15.9 & 6.3 & 184 & $29.9 \%$ & $-0.08[-0.29,0.13]$ & \\
\hline Total $(95 \% \mathrm{Cl})$ & & & 309 & & & 315 & $100.0 \%$ & $-0.35[-0.68,-0.02]$ & \\
\hline \multicolumn{9}{|c|}{$\begin{array}{l}\text { Heterogeneity: } \mathrm{Tau}^{2}=0.08 ; \mathrm{Chi}^{2}=11.60, \mathrm{df}=4(P=0.02) ; I^{2}=66 \% \\
\text { Test for overall effect: } Z=2.09(P=0.04)\end{array}$} & 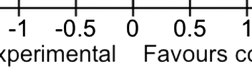 \\
\hline
\end{tabular}

Figure 6 Forest plot of social media for change in dietary fat. 
Table 2 Risk of bias of included studies

\begin{tabular}{|c|c|c|c|c|c|c|c|c|}
\hline Author, year(country) & $\begin{array}{l}\text { Sequence } \\
\text { generation }\end{array}$ & $\begin{array}{l}\text { Allocation } \\
\text { concealment }\end{array}$ & $\begin{array}{l}\text { Blinding of } \\
\text { participants and } \\
\text { personnel }\end{array}$ & $\begin{array}{l}\text { Blinding of } \\
\text { outcome } \\
\text { assessment }\end{array}$ & $\begin{array}{l}\text { Incomplete } \\
\text { outcome data }\end{array}$ & $\begin{array}{l}\text { Selective } \\
\text { outcome } \\
\text { reporting }\end{array}$ & Other & $\begin{array}{l}\text { Overall } \\
\text { RoB }\end{array}$ \\
\hline Booth, 2008 (Australia) & Unclear & Unclear & Unclear & Low & High & Low & Low & High \\
\hline Brindal, 2012 (Australia) & Low & Low & Low & Low & High & Low & Low & High \\
\hline Carr, 2013 (USA) & Low & Low & High & Low & Low & Low & High & High \\
\hline Cavallo, 2012 (USA) & Unclear & Unclear & Unclear & Unclear & Low & Low & Low & Unclear \\
\hline Celio, 2005 (USA) & Unclear & Low & High & Unclear & Low & Low & Low & High \\
\hline DeBar, 2009 (USA) & Low & Low & High & Low & Low & Low & Low & High \\
\hline Ferney, 2009 (Australia) & Low & Unclear & Unclear & Unclear & Low & Low & Unclear & Unclear \\
\hline van Genugten, 2012 (Netherlands) & Low & Unclear & Unclear & Unclear & High & Low & Low & High \\
\hline Gold, 2007 (USA) & Unclear & Unclear & Unclear & Unclear & High & Low & Low & High \\
\hline Gow, 2010 (USA) & Low & Unclear & High & Low & Low & Low & High & High \\
\hline Harvey-Berino, 2004 (USA) & Unclear & Unclear & Unclear & Unclear & High & Low & Low & High \\
\hline Hurling, 2007 (UK) & Unclear & Unclear & Unclear & Low & Unclear & Low & Low & Unclear \\
\hline Lao, 2011 (USA) & Unclear & Unclear & High & High & High & Low & High & High \\
\hline Micco, 2007 (USA) & Unclear & Unclear & Unclear & Unclear & Unclear & Low & High & High \\
\hline Morgan, 2011 (Australia) & Low & Low & Unclear & Low & High & Low & Low & High \\
\hline Pullen, 2008 (USA) & Unclear & Unclear & Unclear & Unclear & High & Low & Unclear & High \\
\hline Rydell, 2005 (USA) & Unclear & Unclear & Unclear & Low & Low & Low & Low & Unclear \\
\hline Spittaels, 2007 (Belgium) & Unclear & Unclear & Unclear & Unclear & Low & Low & High & High \\
\hline Tate, 2001 (USA) & Unclear & Unclear & Unclear & Unclear & High & Low & Low & High \\
\hline Tate, 2006 (USA) & Low & Unclear & Unclear & Unclear & Low & Low & High & High \\
\hline Webber, 2010 (USA) & Unclear & Unclear & Unclear & Low & Low & Low & Low & Unclear \\
\hline Womble, 2004 (USA) & Unclear & Unclear & Unclear & Unclear & High & Low & Low & High \\
\hline
\end{tabular}


Table 3 Results for primary outcomes and conclusions of included studies

\begin{tabular}{|c|c|c|}
\hline Author, year (country) & $\begin{array}{l}\text { Author's } \\
\text { conclusions }\end{array}$ & Conclusions \\
\hline Booth, 2008 (Australia) & Positive & $\begin{array}{l}\text { There was no difference in dietary intake, physical activity and weight loss } \\
\text { between the two groups. Goal setting for increasing exercise seems to be } \\
\text { more effective than for dietary changes. A larger study with a control group is } \\
\text { needed to confirm any findings }\end{array}$ \\
\hline Brindal, 2012 (Australia) & Neutral & $\begin{array}{l}\text { Social networking features did not demonstrate additive effects in terms of } \\
\text { weight loss and retention. Greater use of the web tools was associated with } \\
\text { greater decrease in weight. More studies are needed to determine why or } \\
\text { how this type of intervention can be used to promote weight loss }\end{array}$ \\
\hline Carr, 2013 (USA) & Neutral & $\begin{array}{l}\text { The intervention programme was efficacious at improving physical activity } \\
\text { levels in relation to publicly available websites initially, but differences in } \\
\text { physical activity levels were not maintained at } 6 \text { months. The lack of } \\
\text { between-groups differences at } 6 \text { months appears to be due to gains in } \\
\text { physical activity levels within the control group from } 3 \text { months to } 6 \text { months } \\
\text { rather than decreased physical activity among the intervention group. Testing } \\
\text { of future Internet interventions is required }\end{array}$ \\
\hline Cavallo, 2012 (USA) & Neutral & $\begin{array}{l}\text { No increases in perceived social support or physical activity levels were seen } \\
\text { over time between groups. However, participant satisfaction with the } \\
\text { programme was high }\end{array}$ \\
\hline Celio, 2005 (USA) & Positive & $\begin{array}{l}\text { Findings suggest a modest reduction in weight status and that body image } \\
\text { and disordered eating behaviours are not impacted. Low participation with } \\
\text { discussion board and food diary noted with a lack of association between } \\
\text { compliance and positive outcomes. Interventions with components at a } \\
\text { community and public policy level may see more benefit }\end{array}$ \\
\hline DeBar, 2009 (USA) & Positive & $\begin{array}{l}\text { No significant difference was found for total body BMD but two anatomic } \\
\text { areas examined showed a significant difference in favour of the intervention } \\
\text { group (spine and trochanter). Authors concluded that a comprehensive } \\
\text { multiple component intervention is effective in improving dietary intake and } \\
\text { increasing bone mineral density in adolescent girls }\end{array}$ \\
\hline Ferney, 2009 (Australia) & Positive & $\begin{array}{l}\text { There was a significant interaction effect for total physical activity which } \\
\text { suggests efficacy of the neighbourhood-focused website over the control } \\
\text { website. Further research is needed to explore effectiveness in a larger } \\
\text { sample }\end{array}$ \\
\hline $\begin{array}{l}\text { van Genugten } 2012 \\
\text { (Netherlands) }\end{array}$ & Neutral & $\begin{array}{l}\text { The programme resulted in stable weight, and changes in dietary intake in the } \\
\text { desired direction, but the tailored intervention was not more effective than } \\
\text { generic information. Low compliance with the programme was noted. More } \\
\text { research is recommended to gain insight into how this type of intervention can } \\
\text { be improved }\end{array}$ \\
\hline Gold, 2007 (USA) & Positive & $\begin{array}{l}\text { This study showed that participants who received a structured, therapist-led } \\
\text { behavioural online intervention lost significantly more weight than those who } \\
\text { had access to a self-help commercial weight loss website. Weight loss in both } \\
\text { groups was observed only during the first } 6 \text { months of the study. There was } \\
\text { decreased web usage from months } 6 \text { to } 12 \text { in both groups }\end{array}$ \\
\hline Gow, 2010 (USA) & Positive & $\begin{array}{l}\text { The combination of an Internet-based intervention with weight and caloric } \\
\text { intake feedback showed promise; however, lower intensity interventions such } \\
\text { as the Internet alone were not shown to be effective for preventing weight } \\
\text { gain }\end{array}$ \\
\hline $\begin{array}{l}\text { Harvey-Berino, } 2004 \\
\text { (USA) }\end{array}$ & Neutral & $\begin{array}{l}\text { The results of this study showed that the Internet was an effective vehicle for } \\
\text { promoting long-term clinically significant levels of weight loss. No significant } \\
\text { weight loss differences between groups. Further research is warranted }\end{array}$ \\
\hline Hurling, 2007 (UK) & Positive & $\begin{array}{l}\text { A significant increase in physical activity was observed in the intervention } \\
\text { group over the control group. Because this was a complex intervention, it is } \\
\text { difficult to determine what aspects of the programme contributed most to } \\
\text { positive behavioural change; more research is needed to clarify this }\end{array}$ \\
\hline Lao, 2011 (USA) & Neutral & $\begin{array}{l}\text { Social media use did not yield a significant change in each health behaviour } \\
\text { goal. These results show multiple challenges persist in stimulating } \\
\text { behavioural change with social networking methods in adolescents including } \\
\text { lack of engagement and attrition }\end{array}$ \\
\hline
\end{tabular}


Table 3 Continued

\begin{tabular}{|c|c|c|}
\hline Author, year (country) & $\begin{array}{l}\text { Author's } \\
\text { conclusions }\end{array}$ & Conclusions \\
\hline Micco, 2007 (USA) & Neutral & $\begin{array}{l}\text { Monthly in-person therapy did not improve weight-loss outcomes of an online } \\
\text { weight-loss programme. Use declined over the course of the intervention }\end{array}$ \\
\hline Morgan, 2011 (Australia) & Neutral & $\begin{array}{l}\text { This study has demonstrated that men can maintain clinically important and } \\
\text { statistically significant weight loss at } 12 \text { months following low-dose } \\
\text { intervention programmes. Men did not engage in the online discussion board. } \\
\text { Additional research needed to determine the optimal balance between online } \\
\text { and face-to-face interaction and improve compliance. Less than } 50 \% \text { of men } \\
\text { complied with the recommended intervention }\end{array}$ \\
\hline Pullen 2008 (USA) & Positive & $\begin{array}{l}\text { It is feasible for women aged } 50-69 \text { residing in rural areas to access the } \\
\text { Internet to lose weight. Low participation was a problem. There is need for } \\
\text { research to address this problem }\end{array}$ \\
\hline Rydell, 2005 (USA) & Neutral & $\begin{array}{l}\text { A web-based intervention alone may not be effective to change behaviour } \\
\text { among youth. They may be useful as part of a multiple component } \\
\text { intervention; however, more research is needed to encourage and maintain } \\
\text { use of the web-based component }\end{array}$ \\
\hline $\begin{array}{l}\text { Spittaels, } 2007 \\
\text { (Belgium) }\end{array}$ & Positive & $\begin{array}{l}\text { Intervention was able to increase physical activity but retention and } \\
\text { engagement are important challenges to consider. More research is needed } \\
\text { to determine optimal intensity of intervention }\end{array}$ \\
\hline Tate, 2001 (USA) & Positive & $\begin{array}{l}\text { There was significantly higher weight loss and decrease in waist } \\
\text { circumference in the intervention compared with the control; however, no } \\
\text { difference in exercise and diet between groups was detected. Low } \\
\text { contribution to the discussion board and self-report diary were noted. The } \\
\text { Internet seems like a viable intervention method and deserves more research }\end{array}$ \\
\hline Tate, 2006 (USA) & Neutral & $\begin{array}{l}\text { Email counseling improves weight loss compared with educational sites or } \\
\text { more interactive sites that include behavioural tools but provide no feedback } \\
\text { on behaviour change over time. Further research is needed to enhance these } \\
\text { interventions and increase adherence }\end{array}$ \\
\hline Webber, 2010 (USA) & Neutral & $\begin{array}{l}\text { Both groups lost weight over time and there was no significant difference } \\
\text { between groups. Poor attendance at group chats was noted. Programme use } \\
\text { was associated with more weight loss }\end{array}$ \\
\hline Womble, 2004 (USA) & Neutral & $\begin{array}{l}\text { This study's principal finding was that eDiets.com produced minimal weight } \\
\text { loss and was not as effective as a traditional manual-based approach. } \\
\text { Participant attendance decreased significantly over the course of the study }\end{array}$ \\
\hline
\end{tabular}

interventions. ${ }^{39}$ End-user engagement during the development of the intervention is a method that could be attempted in future research to decrease attrition; ${ }^{40}$ offering financial incentives may also decrease attrition. ${ }^{41}$ Study duration and follow-up should also be increased to examine long-term effects of healthy diet and exercise interventions as regaining weight or falling into old behaviours can be a setback in the long term.

\section{Limitations}

While we used a methodologically rigorous design for our review, the validity of our results may be limited by the quality of the primary studies we included. There was poor reporting of methods for sequence generation, allocation concealment and blinding of participants and personnel and outcome assessment in the included studies. Future RCTs should take this into consideration and follow standards for designing and reporting the study (eg, CONSORT).$^{42}$ In many cases, non-significant between-group findings were seen due to improvement in the intervention and control groups. This may have been a consequence of poor blinding of participants or a Hawthorne effect, whereby the participants showed a change in behaviour as a result of being studied. Measures were also typically self-reported which may have led to social desirability bias.

Recruitment for primary studies was on a voluntary basis. This may have resulted in increased participant motivation and selection bias. Losses to follow-up were very high in included studies, which can impact the validity of meta-analyses and more generally the utility of the intervention. Further, many authors commented on the challenges of adherence and keeping the participants engaged. Those considering social media as part of an intervention should not assume that the target audience will be engaged simply on the premise that social media is popular and widespread. Involving end-users from the target audience in selecting the intervention components and providing feedback during the intervention development may help optimise uptake and adherence. ${ }^{40}$ The high attrition rates also have implications on the ability to generalise results. Populations involved in these studies were also typically fairly homogenous, comprising mainly 
female, Caucasian participants of a higher socioeconomic status, further affecting the ability to generalise results.

The complexity of the interventions studied and the fact that social media may only play a small part, or no part, if programme adherence is low, in the intervention makes it difficult to assess the relative impact of social media.

\section{CONCLUSIONS}

Social media may provide certain advantages for public health interventions because it is popular, it can reach a large and diverse audience and may be relatively less expensive to administer and maintain. However, studies of social media interventions to date relating to healthy diet and exercise tend to show low levels of participation and adherence, and do not show significant differences between groups in key outcomes. Despite its growing popularity, there is little evidence that social media interventions demonstrate a significant benefit for improving healthy diet and exercise. As social media is an ever changing technology, future research is needed to continue to evaluate its effectiveness as a healthcare tool, particularly in combination with other modalities that show some utility such as tailored feedback and in-person support. Involving the end-users from the target audience in the selection and development of the social media intervention may optimise uptake and adherence.

Acknowledgements The authors thank Andrea Milne for conducting the literature searches. They also thank Baljot Chahal, Annabritt Chisholm and Michelle Foisy for assistance with study selection.

Contributors GW, MPH and LH designed the study and interpreted the data. GW coordinated the project. GW, MPH and JS screened articles and performed data extraction. BV contributed to the study design and statistical analyses. GW drafted and all authors critically reviewed the manuscript. All authors read and approved the manuscript. LH is the guarantor.

Funding This study was funded in part through a knowledge synthesis Grant from the Canadian Institutes of Health Research, grand number 262961 and a Knowledge-to-Action Grant from Alberta Innovates-Health Solutions, grant number AIHS KTAG 201201175

Competing interests GW was funded through the University of Alberta Research Experience (U ARE) internship programme. LH holds a New Investigator Salary Award from the Canadian Institutes of Health Research.

Ethics approval As this review used only published materials as sources of information, no ethics approval was needed.

Provenance and peer review Not commissioned; externally peer reviewed.

Data sharing statement No additional data are available.

Open Access This is an Open Access article distributed in accordance with the Creative Commons Attribution Non Commercial (CC BY-NC 3.0) license, which permits others to distribute, remix, adapt, build upon this work noncommercially, and license their derivative works on different terms, provided the original work is properly cited and the use is non-commercial. See: http:// creativecommons.org/licenses/by-nc/3.0/

\section{REFERENCES}

1. WHO. Obesity and Overweight. Secondary Obesity and Overweight. 2013. http://www.who.int/mediacentre/factsheets/fs311/en/index.htm

2. WHO. Obesity: preventing and managing the global epidemic: report of a WHO consultation. Geneva: WHO Consultation on Obesity, 2000.
3. Marks JT, Campbell MK, Ward DS, et al. A comparison of web and print media for physical activity promotion among adolescent girls. $J$ Adolesc Health 2006;39:96-104.

4. Lachausse RG. My student body: effects of an internet-based prevention program to decrease obesity among college students. J Am Coll Health 2012;60:324-30.

5. Robroek SJW, Polinder S, Bredt FJ, et al. Cost-effectiveness of a long-term Internet-delivered worksite health promotion programme on physical activity and nutrition: a cluster randomized controlled trial. Health Educ Res 2012;27:399-410.

6. Ezendam NPM, Brug J, Oenema A. Evaluation of the web-based computer-tailored FATaintPHAT intervention to promote energy balance among adolescents: results from a school cluster randomized trial. Arch Pediatr Adolesc Med 2012;166:248-55.

7. Hersey JC, Khavjou O, Strange LB, et al. The efficacy and cost-effectiveness of a community weight management intervention: a randomized controlled trial of the health weight management demonstration. Prev Med 2012;54:42-9.

8. Kaplan AM, Haenlein M. Users of the world, unite! The challenges and opportunities of social media. Bus Horiz 2010;53:59-68.

9. Moorhead SA, Hazlett DE, Harrison L, et al. A new dimension of health care: systematic review of the uses, benefits, and limitations of social media for health communication. J Med Internet Res 2013;15:e85.

10. Hamm MP, Chrisholm A, Shulhan J, et al. Social media use among patients and caregivers: a scoping review. BMJ Open 2013;3: e002819.

11. Higgins JPT, Green S, eds. Cochrane handbook for systematic reviews of interventions version 5.1.0 [updated March 2011]. The Cochrane Collaboration, 2011.

12. Egger M, Smith GD, Schneider M, et al. Bias in meta analysis detected by a simple, graphical test. BMJ 1997;315:629-34.

13. Booth $A O$, Nowson CA, Matters $H$. Evaluation of an interactive, Internet-based weight loss program: a pilot study. Health Educ Res 2008;23:371-81.

14. Brindal E, Freyne J, Saunders I, et al. Features predicting weight loss in overweight or obese participants in a web-based intervention: randomized trial. J Med Internet Res 2012;14:e173.

15. Carr LJ, Lewis B, Hartman S, et al. Randomized controlled trial testing an internet physical activity intervention for sedentary adults. Health Psychol 2013;32:328-36.

16. Cavallo DN, Tate DF, Ries AV, et al. A social media-based physical activity intervention: a randomized controlled trial. Am J Prev Med 2012;43:527-32.

17. Celio AA. Early intervention of eating- and weight-related problems via the internet in overweight adolescents: a randomized controlled trial. Dissertation Abstracts International: Section B: The Sciences and Engineering, 2005.

18. DeBar LL, Dickerson J, Clarke G, et al. Using a website to build community and enhance outcomes in a group, multi-component intervention promoting healthy diet and exercise in adolescents. $J$ Pediatr Psychol 2009;34:539-50.

19. Ferney SL, Marshall AL, Eakin EG, et al. Randomized trial of a neighborhood environment-focused physical activity website intervention Prev Med 2009;48:144-50.

20. van Genugten $L$, van Empelen $P$, Boon $B$, et al. Results from an online computer-tailored weight management intervention for overweight adults: randomized controlled trial. J Med Internet Res 2012;14:e44.

21. Gold BC, Burke S, Pintauro S, et al. Weight loss on the web: a pilot study comparing a structured behavioral intervention to a commercial program. Obesity 2007;15:155-64.

22. Gow RW, Trace SE, Mazzeo SE. Preventing weight gain in first year college students: an online intervention to prevent the "freshman fifteen". Eat Behav 2010;11:33-9.

23. Harvey-Berino J, Pintauro S, Buzzell P, et al. Effect of internet support on the long-term maintenance of weight loss. Obes Res 2004;12:320-9.

24. Hurling $\mathrm{R}$, Catt $\mathrm{M}$, Boni $\mathrm{MD}$, et al. Using internet and mobile phone technology to deliver an automated physical activity program: randomized controlled trial. J Med Internet Res 2007;9:e7.

25. Lao L. Evaluation of a social networking based SNAP-Ed nutrition curriculum on behavior change [1501411]. University of Rhode Island, 2011.

26. Micco N, Gold B, Buzzell P, et al. Minimal in-person support as an adjunct to internet obesity treatment. Ann Behav Med 2007;33:49-56.

27. Morgan PJ, Lubans DR, Collins CE, et al. 12-Month outcomes and process evaluation of the SHED-IT RCT: an internet-based weight loss program targeting men. Obesity 2011;19:142-51.

28. Pullen $\mathrm{CH}$, Hageman PA, Boeckner L, et al. Feasibility of Internet-delivered weight loss interventions among rural women ages 50-69. J Geriatr Phys Ther 2008;31:105-12. 
29. Rydell SA, French SA, Fulkerson JA, et al. Use of a web-based component of a nutrition and physical activity behavioral intervention with girl scouts. J Am Diet Assoc 2005;105:1447-50.

30. Spittaels H, De Bourdeaudhuij I, Vandelanotte C. Evaluation of a website-delivered computer-tailored intervention for increasing physical activity in the general population. Prev Med 2007;44: 209-17.

31. Tate DF, Wing RR, Winett RA. Using Internet technology to deliver a behavioral weight loss program. JAMA 2001;285:1172-7.

32. Tate DF, Jackvony EH, Wing RR. A randomized trial comparing human e-mail counseling, computer-automated tailored counseling, and no counseling in an Internet weight loss program. Arch Intern Med 2006;166:1620-5.

33. Webber KH, Tate DF, Ward DS, et al. Motivation and its relationship to adherence to self-monitoring and weight loss in a 16-week Internet behavioral weight loss intervention. J Nutr Educ Behav 2010;42:161-7.

34. Womble LG, Wadden TA, McGuckin BG, et al. A randomized controlled trial of a commercial internet weight loss program. Obes Res 2004;12:1011-18.

35. Tuah NA, Amiel C, Qureshi S, et al. Transtheoretical model for dietary and physical exercise modification in weight loss management for overweight and obese adults. Cochrane Database Syst Rev 2011;(10):CD008066.

36. Tsai AG, Wadden TA. Systematic review: an evaluation of major commercial weight loss programs in the United States. Ann Intern Med 2005;142:56-66.

37. Kohl LF, Crutzen R, de Vries NK. Online prevention aimed at lifestyle behaviors: a systematic review of reviews. J Med Internet Res 2013;15:e146. doi:http://dx.doi.org/10.2196/jmir.2665

38. Spring B, Duncan JM, Janke EA, et al. Integrating technology into standard weight loss treatment: a randomized controlled trial. JAMA Intern Med 2013;173:105-11.

39. Eysenbach G. The law of attrition. J Med Internet Res 2005;7.

40. Hartling L, Scott S, Pandya R, et al. Storytelling as a communication tool for health consumers: development of an intervention for parents of children with croup. Stories to communicate health information. BMC Pediatr 2010;10.

41. Spring B, Schneider K, Mcfadden HG, et al. MultipleBehavior Changes in Diet and Activity. Arch Intern Med 2012;172: 789-96.

42. Schulz KF, Altman DG, Moher D, et al. CONSORT 2010 Statement: updated guidelines for reporting parallel group randomised trials. Br Med J 2010;340:698-702. 